\title{
ELECTORAL ALLIANCES IN AFRICA \\ What Do We Know, What Can We Do?
}

\author{
Matthijs Bogaards \\ Matthijs Bogaards is Professor of Political Science at \\ Jacobs University, Bremen, Germany. \\ e-mail: m.bogaards@jacobs-university.de
}

\begin{abstract}
Under what circumstances do opposition parties form electoral alliances, when are they successful, and how do they contribute to democratisation? These are the leading questions in recent studies of opposition coalitions. This article reviews the quantitative literature on pre-electoral coalitions in Africa and beyond. Although differences in operationationalisation, periodisation, case selection and research design hinder the accumulation of knowledge, the tendency is for the quantitative literature to highlight government policies, opposition features and the economy, whereas the qualitative literature focuses on institutions. In addition, this article points to the party system as a variable in its own right. Shifting from the empirical to the prescriptive, the conclusion discusses an institutional innovation that would help to strengthen opposition coalitions in Africa.
\end{abstract}

\section{INTRODUCTION}

Coalition governments have always been rare in Africa (Oyugi 2006). At the time of independence coalitions were formed in a small number of Anglophone colonies. After the third wave of democratisation reached Africa in the 1990s coalition governments remained rare. ${ }^{1}$ A combination of presidentialism and dominant (authoritarian) party systems around the continent has resulted in single-party governments. The 'governments of national unity' in Kenya and Zimbabwe are unhappy marriages born out of election-related violence. They are heavily criticised in the political science literature for being unconducive to democratisation and long-term peace (Sriram \& Zahar 2009; Cheeseman \& Tendi 2010; LeVan 2011).

1 Resnick (this issue) counts more coalition governments in Africa than Oyugi (2006). 
Electoral alliances are much more common than coalition governments, though they occur only in some places and at some times. In recent years several studies have been published that seek to explain this variation in Africa (Arriola 2013) and elsewhere (Wahman 2011; Gandhi \& Reuter 2013). Other scholars are more interested in the consequences of electoral alliances in Africa (Resnick 2013) and beyond (Wahman 2013). The focus in this new literature has been on opposition coalitions, reflecting a preoccupation with the way cooperation among opposition parties contributes to alternation in power and democratic transition. This democratisation bias is also clear from the case selection: recent quantitative studies on opposition coalitions concentrate on elections in electoral authoritarian regimes (Wahman 2011, 2013; Gandhi \& Reuter 2013).

This article has three aims. First, it reviews the recent quantitative literature on coalitions in Africa and beyond in order to take stock of our existing knowledge about this important phenomenon. Next, the article develops the argument that coalitions should be understood in the context of party systems. Different types of party system, democratic as well as authoritarian, offer different incentives for pre-electoral alliance formation, resulting in a range of dynamics and patterns. The article concludes with a proposal to strengthen the opposition in African parliaments through an institutional incentive for opposition coalitions.

\section{THE COMPARATIVE QUALITATIVE LITERATURE}

Kadima (2006a) has pioneered the study of electoral alliances in Africa. His edited volume with case studies of South Africa, Malawi, Mozambique, Kenya and Mauritius provides the first systematic treatment of this topic. Kadima (2006b, p 10) defines a party coalition as 'the coming together of a minimum of two political parties for a certain period, in pursuit of an agreed set of common goals to be reached by means of a common strategy, joint actions, the pooling of resources and the distribution of possible subsequent pay-offs' ${ }^{2}$

In addition to descriptive detail, four features distinguish Kadima's study from most of the recent quantitative literature on party alliances reviewed below. First, a broad interest in the factors that influence the formation, survival, and effectiveness of party coalitions as well as their impact on the party system and national cohesion, though 'the general argument linking stable coalition governments with deepening democracy is fuzzy' (Jua 2007, p 521). Second, Kadima's study extends to party coalitions involving the ruling party, whereas most of the contemporary literature only has eyes for opposition parties. Third,

2 Following the literature, this article uses the terms 'electoral alliances', 'electoral coalitions' and 'preelectoral coalitions' interchangeably. 
Kadima's study also covers party splitting and floor crossing. ${ }^{3}$ This helps in better understanding the dynamics of coalition formation and collapse. Fourth, Kadima's study has a normative dimension in that it seeks to formulate recommendations for good practice. Thus, the conclusion finishes with a list of measures that would help to improve the durability, effectiveness and democratic quality of party coalitions. One suggestion, which has been criticised by Jua (2007, p 519) as being too detailed and demanding, is that 'because political parties and coalitions are institutions of public interest, the law should provide for the registration of coalitions and require that their objectives, duration and agreement are made public' (Kadima 2006c, p 238).

\section{QUANTITATIVE STUDIES OF ELECTORAL ALLIANCES IN AFRICA}

Arriola's (2013) book on multiethnic coalitions in Africa is the most comprehensive and ambitious study of the topic since Kadima (2006). It starts with the observation that alternation in power is less frequent in Africa than in other regions. This is due in part to a lack of opposition coordination. Arriola (2013, p 7) estimates that in $40 \%$ of the 74 presidential elections won by incumbents the top three opposition challengers together collected more votes than the candidate of the ruling party.

If the reasons for working together are so obvious, why, then, does the opposition fail to form pre-electoral coalitions more often ${ }^{4}$ Arriola's answer is: money. His 'pecuniary theory of coalition building' highlights the crucial role of capital. The argument goes like this: in Africa's multiethnic societies political leaders are expected to provide patronage. This is much easier for the incumbents, who have access to the state, than the opposition, resulting in a resource asymmetry. In order to win elections the opposition normally has to join forces, but this is complicated by the ethnic nature of party politics. The spoils of collaboration are uncertain because, firstly, the coalition might not win the elections, and secondly, there is no guarantee that once in office the winning candidate will keep his or her promise to share power and resources. In other words, any potential leader of the unified opposition faces a credible commitment problem. It is not enough to promise rewards after the elections, the would-be-leader of an opposition coalition

3 Other studies on floor crossing in Africa include Goeke \& Hartmann (2011), who seek to demonstrate that anti-party switching laws helped to stabilise patterns of inter-party competition, and Booysen (2006), who observes how floor-crossing legislation in South Africa weakened the opposition and strengthened the dominant-party system.

4 One way of finding this out is by asking the opposition. Huskey \& Iskakova (2010) interviewed opposition politicians in Kyrgyzstan and asked them to rate how important factors such as divideand-rule policies of the incumbents, economic conditions, policy differences, personal ambitions, ethnicity, and trust were in complicating cooperation within the opposition. The results were sometimes surprising, for example, the low salience of money and identity. 
has to distribute rewards before the elections. In Arriola's (2013, p 27) words: 'In patronage-based polities across Africa, politicians must be able to pay upfront for the cross-ethnic endorsements that make up electoral alliances.'

But with what means? The answer is: private business. Private business, however, will only dare to support the opposition when this does not threaten its access to credit. From independence onwards African governments have sought to establish state control of capital. Thus, only where financial liberalisation has taken place, usually because of political conditionality following the economic crisis of the 1980s, is private business free from the fear of financial reprisals by the state, allowing it to support the opposition. Absent financial liberalisation the opposition will remain fragmented.

Arriola (2013, p 28) is right to note that 'scholars have overlooked the role of business in supplying vital resources to the opposition in multiethnic developing countries', but not everybody will be convinced by his mono-causal story. ${ }^{5}$ The empirical study combines a paired comparison of Kenya and Cameroon with a statistical analysis of all cases. Arriola (2013, p 36) defines a coalition as 'an electoral alliance in which politicians from different ethnic or regional groups endorse a single candidate for executive office'. Only coalitions of 'politically relevant actors' are included (p 211). While the aim is clear and the justification plausible, the criteria are not. Arriola relies on 'parliamentary representation' or 'expert assessments found in country case studies' ( $p$ 211) but does not provide coding rules that allow for replication.

The data set includes 85 multiparty elections for the executive in the period 1990-2005. Of these, 32 were contested by an opposition coalition. Surprisingly perhaps, 'there is no continuous increase or decrease in the incidence of opposition electoral coordination over time' (Arriola 2013, p 212), which might be interpreted as a lack of political learning. ${ }^{6}$ The figure is low in international comparison, something Arriola ( $\mathrm{p}$ 211) attributes to Africa's presidential systems and the frequency of elections that are not free and fair. While plausible, his empirical analysis does not test these insights, which could have been done by distinguishing parliamentary from presidential elections and using the quality of elections as a variable. ${ }^{7}$ The quantitative analysis shows economic growth to have the strongest positive impact on coalition formation, indirectly confirming the importance of resources. The availability of private credit and the number of commercial banks are also positively related to the number of coalitions. ${ }^{8}$

5 For an enthusiastic book review see Bleck (2013), for a more critical reception, see Eizenga (2014).

6 In contrast, Resnick (this issue) shows a dramatic rise in the number of electoral coalitions in the new millennium.

7 Data on quality of elections for the period is available from Lindberg (2006).

8 The size of coalitions plays no role in Arriola's (2013) analysis. 
Although Arriola claims (2013, p 3) that 'this book engages such questions in the context of Africa's incomplete democratisation' and situates his theory in the literature on hybrid regimes (p 9), regime type is, in fact, only of minor importance to his theory and empirical analysis. In the statistical analysis Arriola does test one hypothesis that seems to capture the regime variable: 'Greater democratic experience should increase the likelihood of multiethnic opposition coalition formation' ( $\mathrm{p}$ 218). However, 'democratic experience' is measured as the number of previous multiparty elections, irrespective of whether these elections were reasonably free and fair. Arriola's use of 'democratic experience' does not distinguish electoral democracies from electoral autocracies and it comes as little surprise that the variable is statistically insignificant.

In the expectation that opposition coordination is even more difficult in authoritarian regimes, Arriola (2013) includes a measure of democracy in his models. What he finds is the opposite: 'opposition coalitions are more likely to emerge under more authoritarian conditions' ( $\mathrm{p} 232$ ), an outcome, Arriola speculates, which might be explained by the perceived need on the part of the opposition to unite in the face of an authoritarian incumbent who will use fraud or other undemocratic means to stay in power. This points again to the need to separate electoral democracies and electoral authoritarian regimes in the analysis of opposition alliances.

If politicans 'have no means of enforcing any power-sharing promises' and if in 'the weakly institutionalised conditions in which politicians vie for office in democratizing countries, politicians cannot expect to rely on institutional mechanisms to enforce a pre-electoral agreement' (Arriola 2013, p 31), as happened, for example, in Kenya, this diagnosis seems to call for institutional reform along the lines proposed by Kadima (2006c), as we saw above. However, Arriola does not draw this conclusion and his only policy recommendation is not to overregulate campaign finance lest this scare away business from supporting the opposition.

Whereas Arriola (2013) seeks to explain the occurrence of opposition alliances in Africa, Resnick (2013) examines the outcome of opposition coalitions. She identifies two major challenges facing African opposition parties: incumbency advantage and a lack of distinct political programmes. Pre-electoral coalitions are seen as a way to overcome these obstacles. Resnick treats electoral coalitions as an independent variable. She does present data on the electoral system used for presidential and legislative elections, but this serves merely to note that 'opposition coalitions are formed across a range of electoral institutions' ( $\mathrm{p} 743$ ). The dependent variable is 'consolidation', defined in terms of turnover and party system institutionalisation. 
Resnick (2013) looks exclusively at electoral democracies, identified with the help of Freedom House. ${ }^{9}$ She argues that the challenges of defeating incumbents and articulating a distinct policy agenda are often impossible when elections are not free and fair and where opposition parties lack the freedom to campaign' (p 740), although this overstates the ability of authoritarian regimes to win elections (see the contributions to Lindberg 2009). Her conclusions are largely pessimistic, noting that 'opposition coalitions rarely have defeated incumbent parties in either presidential or parliamentary elections' and that volatility among members of opposition alliances has 'contributed from one-third to two-thirds of total electoral volatility' (Resnick 2013, p 751).

Both conclusions can be disputed. First, the disappointing success record of opposition alliances in Resnick's study, which stands in contrast to the figures presented by Arriola (2013), may be due to differences in the operationalisation of electoral coalitions. Resnick broadly defines (opposition) coalitions as the coming together under one banner of any two or more parties and also non-agression pacts in which parties promise not to compete for the same legislative seats (Resnick 2013, p 736). ${ }^{10}$ Thus, she registers the 'Grand Coalition' of three (very) minor parties around Edward Mahama in the Ghanaian presidential elections of 2004. Mahama received less than $2 \%$ of the vote and Resnick records this as an instance of an opposition coalition unable to defeat the incumbent. Arriola (2013), on the other hand, does not detect a coalition in $2004 .{ }^{11}$ In the context of Ghana's two-party system, Arriola's coding rules seem more appropriate than Resnick's. Second, the opposition can only win power if it wins votes at the expense of the ruling party. Bogaards (2008) therefore calculates 'incumbent vote change' to distinguish between countries where the opposition is able to encroach upon the incumbents and those 'where volatility is largely caused by a game of changing chairs among opposition parties' ( $\mathrm{p} 122$ ).

Resnick's measure of 'opposition coalition volatility as share of total volatility' only captures that part of intra-opposition volatility that occurs among the members of the alliance she identifies. In other words, her measure is bound to understate the degree to which the opposition is preying on itself. Moreover, Resnick (2013) has very few observations, making it difficult to draw firm conclusions. ${ }^{12}$ Finally, no systematic attempt is made to explain the variation on the dependent variables(s).

9 See: www.freedomhouse.org

10 On party nomination strategies in Africa, see Ishiyama (2009) and Stroh (2010).

11 Arriola (2013, p 263) does code a coalition between the New Patriotic Party (NPP), one of the pillars of the current two-party system, and the People's Convention Party (PCP) in 1996.

12 Bogaards (2008) examines electoral volatility over 78 elections in the 20 African countries that, by the time of writing, had enjoyed at least three consecutive multiparty elections. 


\section{ELECTORAL ALLIANCES AROUND THE WORLD}

As in the African literature, studies that examine electoral alliances globally can be distinguished by the role of electoral alliances as dependent (Wahman 2011; Gandhi \& Reuter 2013) or independent (Wahman 2013) variable. As is the case with the African literature, worldwide analyses of pre-electoral coalitions are mostly concerned with opposition alliances and motivated by an interest in democratisation. In contrast with the African literature, though, cross-regional studies of electoral alliances give a more prominent role to regime type, also distinguishing between different types of electoral authoritarianism.

Wahman (2011) examines electoral coalitions in competitive authoritarian regimes for the period 1989-2004. To distinguish competive from noncompetitive - or what the American literature calls 'hegemonic authoritarian' regimes, Wahman (p 647) adopts the admittedly 'arbitrary' threshold of two-thirds of the seats in Parliament for the ruling party. When the largest opposition party is part of a pre-electoral alliance with the second and / or third opposition party, this is labelled a 'coalition of contestation'. The standing of opposition parties is based on vote share in the 'current election' ( $p$ 655). When the second- and thirdplaced opposition parties form a coalition without the main opposition party, this is labelled a 'marginal coalition'. As a consequence, while Arriola (2013) and Resnick (2013) register the 'alliance' that won Senegal's 2000 presidential elections, Wahman codes Senegal as not having had a coalition that year.

Wahman (2011) finds that the more the government and the main opposition party differ on policies - as reported by their voters - the more likely there is to be an opposition electoral coalition, at least when all three main opposition parties are located on the same side (to the left or to the right) of the government. It should be noted though, that policy congruence is measured by comparing the ruling, party and the main opposition party. In other words, this measure says very little about opposition coherence. Wahman also finds a statistically significant result for negative economic growth and liberalisation in the year leading up to the election, both contributing to the probability of the formation of an electoral coalition.

No information on parties' policy positions is available for half of the cases in Wahman's study. One suspects the percentage to be even larger for the African subset, rendering any conclusions about the importance of policy congruence for African coalition formation highly dubious. Kadima (2006c) noted that in his study 'ideology has not been an essential factor in party coalition building or splitting in any of the five countries'. Although Wahman (2011, p 648) acknowledges that ethnic orientation might matter as much as policy positions, he does not incorporate this variable into the analysis because of a lack of data. In 
the conclusion Wahman is sceptical about what he calls 'opportunistic coalitions' in 'non-ideological party systems' and doubts that these coalitions contribute to democratisation, even if they result in turnover ( $\mathrm{p}$ 655). No separate analysis is available of the subset of African cases in Wahman's study, 26 elections of which featured a coalition.

Gandhi \& Reuter (2013) cover much the same ground as Wahman (2011). Like him, they want to know which factors contribute to the formation of pre-electoral coalitions in non-democratic elections. Their dataset consists of 413 multiparty elections with 65 opposition coalitions for the period 1946-2006. ${ }^{13}$ Most of these coalitions were formed in the past two decades as there is a clear trend over time (Gandhi \& Reuter 2013, p 140). ${ }^{14}$ Gandhi \& Reuter (p 145) specify three reasons why the incentives for coordination in authoritarian multiparty contests should differ from those in democracies.

The first of these is the degree to which there is a level playing field. The government can resort to coercion or cooptation to prevent the opposition from uniting. The second reason is the degree to which actors are certain that the incumbent will cede power. Opposition parties face a dual uncertainty about the outcome of the elections and the reaction of the incumbent to losing. Opposition victory implies regime change, raising the stakes for all involved. The third reason is that mistrust among parties is a typical authoritarian legacy, as 'without a stable past of interaction and with uncertainty about who their bargaining partners might be in the future, parties may find it difficult to form meaningful reputations and future expectations that are conducive to coalition building' (p 146).

Gandhi \& Reuter's empirical analysis distinguishes between two broad sets of independent variables: institutional incentives versus authoritarian factors. Both sets perform poorly in the statistical analysis, with very few variables reaching statistical significance. The number of elections in which the largest opposition party has competed has the strongest positive impact on the formation of an opposition coalition. ${ }^{15}$ If a distinction is made between all opposition coalitions and those involving the largest opposition party one sees that the share of the seats of the ruling party has a negative impact on the first, but not on the second.

13 We are not told which countries were included or how authoritarian regimes were identified. In the tables the number of countries varies from a low of 54 to a high of 94 . Included are all cases in which 'any significant opposition formed a pre-electoral coalition with another opposition party' (Gandhi \& Reuter 2013, p 147), but no list of coalitions is presented. A coalition is considered significant when the members together held more than $5 \%$ of the seats in the previous Parliament and the ratio of the largest to the second-largest party in the coalition is less than 15.

14 The post-communist countries of Eastern Europe and the former Soviet Union have the highest number of opposition coalitions (Gandhi \& Reuter 2013, p 141).

15 Somewhat confusingly, this variable is labelled 'age of largest party', even though age and electoral experience can be two very different things, as is the case, for instance, with the African National Congress in South Africa. 
This suggests an intimidation effect, to which the largest opposition party is immune.

Interestingly, Gandhi \& Reuter (2013, pp 149-150) also look at regime coalitions and find that ethnic fractionalisation makes an electoral coalition around the ruling party more likely, whereas economic growth and the age of the ruling party make it less likely. Electoral authoritarian regimes vary greatly and the literature has attempted to capture these differences by distinguishing between competitive and hegemonic authoritarian regimes. Donno (2013, pp 710-711) shows that opposition coalitions only contribute to democratisation in competitive authoritarian regimes, not in hegemonic authoritarian regimes.

Finally, Wahman (2013) investigates not the causes but the consequences of electoral coalitions. He does so again focusing on elections in competitive authoritarian regimes, but with more countries - 86 instead of 55 - and over a longer period (1973-2004). The first finding is that the predicted probability of an opposition victory is 29 per cent higher in elections where the opposition had formed a coalition' ( $p$ 15). That is the good news. The bad news is that the formation of opposition coalitions as such does not result in what Wahman calls a 'Democratic Electoral Outcome', meaning a positive change on the combined Polity-Freedom House index. Only when the opposition coalition wins the elections is there a democratising effect and even this effect disappears when the Polity democracy index is used by itself. ${ }^{16}$ In other words, what makes the difference for democratisation is not so much whether the opposition formed a pre-electoral coalition but whether it won the elections.

By implication, what we need to know is which factors contribute to the formation of opposition coalitions, under what conditions opposition coalitions contribute to opposition victories and then how opposition victories lead to further democratisation. Unfortunately, while this is the causal chain implicit in Wahman's (2013) analysis, it is not directly tested. ${ }^{17}$ Moreover, Wahman is too pessimistic in his conclusions about the impact of opposition victory. While it is undoubtedly correct to warn that 'alternation in power is not sufficient to transform a country into a democracy' ( $\mathrm{p} 23$ ), his results do show that opposition victory is positively related to democratic progress. Secondly, looking at the situation one year after the elections hardly counts as an examination of the long-term impact of either opposition coalitions or opposition victory.

Wahman (2013) does not provide a separate analysis of the African cases:

16 See: www.systemicpeace.org/polityproject.html.

17 Wahman (2013, p 21) does have one table in which he tests a range of variables, but only one is statistically significant - negative economic growth in the year leading up to the election - as in Wahman (2011) - and the explained variance is extremely low, suggesting that with these variables (among others: electoral system, form of government, level of democracy, modernisation, aid and trade) we are unable to account for the formation of opposition coalitions. 
29 countries with a total of 82 elections, of which 19 featured opposition coalitions. This could easily have been done by including a regional dummy variable and would have been justified by the fact that almost one-third of the elections under consideration took place in Africa. Another reason for a focus on Africa should have been that the article is framed as a test of Lindberg's (2006) theory of democratisation through elections, a theory originally developed to explain the African experience. ${ }^{18}$

\section{PARTY SYSTEMS AND ELECTORAL ALLIANCES}

Wahman (2011, p 647) explicitly excludes 'strict two-party systems' from his analysis, arguing that 'they are not comparable to other instances of oppositional coalition formation'. In the online appendix to his article one can read that this coding rule resulted in the disqualification of three African cases: Comoros 1996, Ghana 2000 and Zimbabwe 2002. We saw above that Arriola (2013) and Resnick (2013) disagreed about the presence of a coalition in the Ghanaian presidential elections of 2004. Wahman presents a way out of this dilemma and points to a larger issue: the role of party systems in understanding alliance dynamics and patterns.

Golder's (2006a, 2006b) analysis, which forms the basis for much of the recent research on electoral alliances, likewise hints at the importance of the party system. It starts with the observation that 'pre-electoral coalitions arise from a bargaining process in which party leaders compare the expected utility from running independently to the expected utility from forming a coalition' (Golder 2006a, p 198). In her study of parliamentary democracies in the developed world Golder finds that the costs and benefits of forming a pre-electoral coalition are affected by the relative size of parties and the extent of polarisation. These are classic party-system properties that occupy a prominent place in Sartori's (1976) typology of party systems.

To indicate the promise of an analysis that examines more systematically the connection between opposition coalitions and party systems, Table 1 brings together party system data from Bogaards (2008) with information on opposition coalitions from Arriola (2013). Many countries are still missing at this point because they had not organised three consecutive parliamentary elections by 2008 , the minimum duration to identify the emerging party system, or because the country is not covered by Arriola (2013).

To determine the type of party system Sartori's counting rules for 'relevant'

18 For a critical re-examination of Lindberg's evidence, see Bogaards $(2013,2014)$. 
parties are used (See Bogaards 2004, 2008). ${ }^{19}$ Relevant are those parties with coalition or blackmail potential, that is, all parties with the potential either to form a coalition or to prevent a coalition from being formed (Sartori 1976, pp 122123). In presidential systems those parties are relevant 'that make a difference in helping (or obstructing) the president's election, and that determine his having (or not having) a majority support in the legislative assemblies' (Sartori 1994, p 34).

Sartori's counting rules are grounded in a typology. In Africa's 'fluid' polities there are four types of multiparty system: dominant authoritarian, dominant, nondominant and pulverised (Sartori 1976, p 260). The non-dominant-party system is described as a situation of 'relatively few parties that actually counterweight one another' ( $\mathrm{p} 258$ ) while a pulverised party system has so many relevant parties that the exact number no longer even matters to inter-party relations. A dominant-party system exists when one party wins an absolute majority in Parliament in at least three consecutive elections and captures the presidency. Of special interest is the dominant authoritarian party system, in which one-party dominance is maintained by non-democratic means. The authoritarian dominant party does not allow for competition on an equal basis. Dominant authoritarian parties are operationalised as dominant parties in authoritarian regimes. To distinguish democracies and non-democracies, Freedom House's designation of a 'free' country or 'electoral democracy' is used..$^{20}$

There are 12 countries for which we have information on the type of party system (from Bogaards 2008) and the formation of opposition coalitions (from Arriola 2013). What do we see in Table 1? Opposition coalitions can be found in all types of party system: pulverised, non-dominant, dominant and dominant authoritarian. With only 12 cases it is impossible to say anything meaningful about frequencies other than that opposition coalitions are not unique to any type of party system and can be found in both democracies and non-democracies. This may seem a trivial finding until one realises that the quantitative literature on opposition coalitions has ignored the party system as a variable of interest. If a party system, following Sartori (1976, p 44, emphasis removed from original), is 'the system of interactions resulting from inter-party competition', then surely the process of fission and fusion is an integral part of that and we need to study the interactions as they occur in the context of the party system as system.

19 For other recent overviews of party systems in Africa, see Lindberg (2007), Erdmann \& Basedau (2008) and Fleischhacker (2010).

20 For more information on measures of democracy as applied to Africa, see Bogaards (2007a, 2007b). 
Table 1

\section{Opposition Coalitions and Party Systems in Africa}

\begin{tabular}{|c|c|c|c|c|c|c|}
\hline Country & $\begin{array}{c}\text { Election } \\
\text { year } \\
\text { (pres.) }\end{array}$ & $\begin{array}{l}\text { Freedom } \\
\text { House }\end{array}$ & $\begin{array}{c}\text { Relevant } \\
\text { parties } \\
\text { (parl.) }\end{array}$ & $\begin{array}{c}\text { Party } \\
\text { system }\end{array}$ & $\begin{array}{l}\text { Turn- } \\
\text { over }\end{array}$ & $\begin{array}{l}\text { Opposition } \\
\text { coalition }\end{array}$ \\
\hline \multirow[t]{3}{*}{ Benin } & 1991 & $\mathrm{~F}$ & $6+$ & pulver & yes & yes \\
\hline & 1996 & $\mathrm{~F}$ & $6+$ & pulver & yes & yes \\
\hline & 2001 & $\mathrm{~F}$ & $6+$ & pulver & & \\
\hline \multirow[t]{3}{*}{ Botswana } & 1994 & $\mathrm{~F}$ & 1 & dom & & \\
\hline & 1999 & $\mathrm{~F}$ & 1 & dom & & \\
\hline & 2004 & $\mathrm{~F}$ & 1 & dom & & \\
\hline \multirow{3}{*}{$\begin{array}{l}\text { Burkina } \\
\text { Faso }\end{array}$} & 1991 & $\mathrm{PF}$ & 1 & dom auth & & \\
\hline & 1998 & $\mathrm{PF}$ & 1 & dom auth & & \\
\hline & 2005 & $\mathrm{PF}$ & 1 & dom auth & & \\
\hline \multirow[t]{3}{*}{ Ghana } & 1992 & $\mathrm{NF}$ & 1 & dom auth & & \\
\hline & 1996 & El dem & 1 & dom & & yes \\
\hline & 2000 & $\mathrm{~F}$ & 2 & non dom & yes & \\
\hline \multirow[t]{3}{*}{ Mauritania } & 1992 & $\mathrm{NF}$ & 1 & dom auth & & yes \\
\hline & 1997 & $\mathrm{NF}$ & 1 & dom auth & & \\
\hline & 2003 & $\mathrm{NF}$ & 1 & dom auth & & yes \\
\hline \multirow[t]{3}{*}{ Mauritius } & 1991 & $\mathrm{~F}$ & 2 to 4 & non dom & & yes \\
\hline & 1995 & $\mathrm{~F}$ & 2 to 4 & non dom & yes & yes \\
\hline & 2000 & $\mathrm{~F}$ & 2 to 4 & non dom & yes & yes \\
\hline \multirow[t]{3}{*}{ Mozambique } & 1994 & $\mathrm{PF}$ & 1 & dom & & \\
\hline & 1999 & El dem & 1 & dom & & yes \\
\hline & 2004 & El dem & 1 & dom & & yes \\
\hline \multirow[t]{3}{*}{ Namibia } & 1994 & $\mathrm{~F}$ & 1 & dom & & \\
\hline & 1999 & $\mathrm{~F}$ & 1 & dom & & \\
\hline & 2004 & $\mathrm{~F}$ & & & & \\
\hline \multirow[t]{2}{*}{ Senegal } & 1993 & $\mathrm{PF}$ & 1 & dom auth & & \\
\hline & 2000 & $\mathrm{~F}$ & 1 & non dom & yes & yes \\
\hline \multirow[t]{3}{*}{ South Africa } & 1994 & Free & 1 & dom & yes & \\
\hline & 1999 & Free & 1 & dom & & \\
\hline & 2004 & Free & 1 & dom & & yes \\
\hline
\end{tabular}




\begin{tabular}{|l|c|c|c|c|c|c|}
\hline \multirow{4}{*}{ Zambia } & 1991 & F & 1 & dom & yes & yes \\
\cline { 2 - 7 } & 1996 & PF & 1 & dom auth & & \\
\cline { 2 - 7 } & 2001 & PF & 1 & dom auth & & \\
\hline Zimbabwe & 1990 & PF & 1 & dom auth & & yes \\
\cline { 2 - 8 } & 1995 & PF & 1 & dom auth & & \\
\cline { 2 - 8 } & 2000 & PF & 1 & dom auth & & \\
\hline
\end{tabular}

Sources: Bogaards 2008; Arriola (2013) on opposition coalition and turnover

Key: F - Free, PF - Partly free, NF - Not free, El dem - Electoral democracy, relevant number of parties in parliamentary elections closest in time to the presidential election.

It is my contention that the formation of opposition coalitions follows a different logic depending on the type of party system. Thus, in a pulverised party system like that in Benin, opposition coalitions are a must to win elections and one would expect all national elections to be contested by coalitions. Hence, in Benin, what needs explanation is not the opposition coalitions that formed for the presidential elections in 1991 and 1996 but their absence in 2001.

In a non-dominant-party system the relative size of the parties matters. In Ghana's two-party system coalitions play no role. In Mauritius only coalitions play a role. These conjectures enable precise predictions about the presence of coalitions in pulverised and non-dominant-party systems without having to resort to the independent variables highlighted in the recent quantitative literature on opposition coalitions.

In a dominant-party system elections are always a game of one versus all. Unless opposition parties have a reason to compete among each other they will focus all their attention on beating the incumbent. Thus, dominant-party systems provide a strong incentive for coalition formation. The question therefore is what prevents the opposition from doing so. One possibility is that, again, relative size matters and that the opposition is so weak that the best it can hope for is to win representation in Parliament. In other words, electoral competition is not about forming the government but about securing seats in a Parliament dominated anyway by the ruling party. ${ }^{21}$

Opposition coalitions, then, only form to secure parliamentary representation in the face of electoral obstacles, as with the electoral threshold in Mozambique (Kadima \& Matsimbe 2006, pp 163-164). Thus, we have an account combining party system and electoral system.

21 In Kraetzschmar's (2011) typology of opposition cooperation, developed for the Middle East, these are called 'vote/seat winning alliances'. 
In dominant authoritarian party systems we expect to find dynamics similar to those in dominant-party systems, albeit in an even more pronounced form. Following Van de Walle (2006) we would expect opposition parties in electoral autocracies to be even clearer about what they want: to replace the government or to secure a modicum of access to resources. We thus need more information about the type of electoral authoritarianism in which the opposition competes (see Bogaards 2014).

In competitive authoritarian regimes opposition parties might see a chance of winning and hence have an incentive to form a coalition. In hegemonic authoritarian regimes opposition parties might resign and simply go for access to the spoils, something better achieved on their own. Or, indeed, by aligning with the ruling party. Hence, to get a fuller picture of the processes of fission and fusion we also need to look at coalitions involving the ruling party and at party switching. Needless to say, at this stage these are still hypotheses in need of empirical corroboration.

\section{CONCLUSION}

The emerging literature on electoral alliances of (opposition) parties in Africa and beyond, in democracies and non-democracies, has identified several variables that are conducive to opposition unity: ideological divergence between the opposition and government, economic decline and political liberalisation (Wahman 2011); the electoral experience of the largest opposition party, government harassment of the opposition, and the seat share of the ruling party (Gandhi \& Reuter 2013) and financial liberalisation (Arriola 2013). Several studies reported insignificant results, perhaps an indication that this type of research is still in its infancy and that the search for the drivers of electoral coalitions and the factors that condition their impact continues. Unfortunately, differences in the definition and operationalisation of the concept of opposition coalition, differences in the scope of the theory and the corresponding set of cases (electoral democracies, electoral autocracies, a particular type of electoral autocracy, all regime types) and differences in periodisation hinder the accumulation of knowledge. Moreover, further research is necessary to determine whether factors highlighted in the African literature, such as ethnicity, are equally important elsewhere and whether results from the global literature, for example about the importance of party ideology, can be replicated in Africa.

One variable missing from the current quantitative literature is the party system itself. The party system is not merely the outcome of processes of splits and mergers but also, as a system, provides incentives for and against electoral alliances. The literature reviewed here agrees that these incentives further differ by 
regime type. A focus on the party system would provide an integrated framework for the study of electoral coalitions, situating them in their respective type of party system.

The current quantitative literature, despite its democratisation bias, has remarkably little to say about ways in which oppositon coalitions can be furthered and strengthened. This is an important omission in comparison to the qualitative study of Kadima (2006a), who advocates institutional measures. However, if the recent quantitative studies agree on one thing, it is that institutional factors, including the electoral system, cannot explain the formation of opposition coalitions. ${ }^{22}$ How, then, can the democratic opposition in Africa be strengthened? ${ }^{23}$

In his comparative study of electoral systems and party systems in developed democracies, Lijphart (1994) explores ways in which electoral engineers can adjust the balance of power between a majority party and the opposition by introducing a majority ceiling and minority premium. In other words, no matter how many votes the leading party wins, it can never get more than, say, $55 \%$ of the seats in Parliament: a majority ceiling. On the other hand, the largest opposition party would, as a rule, get, for example, $35 \%$ of the seats: a minority premium.

Bogaards (2000, pp 177-184) discusses the potential of a majority ceiling and minority premium in African party politics. The aim is to limit the dominance of the ruling party and to strengthen the position in Parliament of the main opposition party. Such over-representation would turn the largest opposition party into a focal point for the opposition, increasing incentives for smaller opposition parties either to join or to form a rival alliance to secure the minority premium. In both cases, alliance formation would result, consolidating the opposition and increasing the chance of turnover and democratisation.

\section{REFERENCES}

Arriola, L R. 2013. Multiethnic Coalitions in Africa: Business Financing of Opposition Election Campaigns. Cambridge: Cambridge University Press.

Bleck, J. 2013. Review of Arriola 2013. Journal of Modern African Studies 51(3).

Bogaards, M. 2000. 'Crafting Competitive Party Systems: Electoral Laws and the Opposition in Africa'. Democratization 7(4).

Bogaards, M. 2004. 'Counting Parties and Identifying Dominant Party Systems in Africa'. European Journal of Political Research 43(2).

22 The qualitative literature tells a very different story. See, eg, Kapa (2008) on electoral system reform and pre-election coalitions in Lesotho.

23 Donors might also play a role. One intriguing question is whether the support of the Netherlands Institute for Multiparty Democracy for inter-party dialogue (See Rakner \& Svåsand 2010) has facilitated the formation of electoral alliances by increasing trust. 
Bogaards, M. 2007a. 'Measuring Democracy through Election Outcomes: A Critique with African Data'. Comparative Political Studies 40(10).

Bogaards, M. 2007b. 'Elections, Election Outcomes and Democracy in Southern Africa'. Democratization 14(1).

Bogaards, M. 2008. 'Electoral Volatility and Dominant Party Systems in Africa: A Comment on Mozaffar and Scarritt'. Party Politics 14(1).

Bogaards, M. 2013. 'Reexamining African Elections'. Journal of Democracy 24(4).

Bogaards, M. 2014. 'Multiparty Elections in Africa: For Better or Worse'. In R Doorenspleet \& L Nijzink (eds). Political Parties, Party Systems and Democracy in Africa. Basingstoke: Palgrave Macmillan, forthcoming.

Booysen, S. 2006. 'The Will of the Parties Versus the Will of the People? Defections, Elections and Alliances in South Africa'. Party Politics 12(6).

Cheeseman, N \& B-M Tendi. 2010. 'Power-Sharing in Comparative Perspective: The Dynamics of "Unity Government" in Kenya and Zimbabwe. Journal of Modern African Studies 48(2).

Donno, D. 2013. 'Elections and Democratization in Authoritarian Regimes'. American Journal of Political Science 57(3).

Eisenga, D. 2014. Review of Arriola 2013. African Studies Review 57(1).

Erdmann, G \& M Basedau. 2008. 'Party Systems in Africa: Problems of Categorising and Explaining Party Systems'. Journal of Contemporary Studies 26(3).

Fleischhacker, H. 2010. Parteiensystem und Verfassung in Afrika: Strukturen Funktionen - Typen. Wiesbaden: VS Verlag für Sozialwissenschaften.

Gandhi, J \& O J Reuter. 2013. ‘The Incentives for Pre-Electoral Coalitions in NonDemocratic Elections'. Democratization 20(1).

Goeke, M \& C Hartmann. 2011. 'The Regulation of Party Switching in Africa'. Journal of Contemporary African Studies 29(3).

Golder, S N. 2006a. 'Pre-Electoral Coalition Formation in Parliamentary Democracies'. British Journal of Political Science 36(3).

Golder, S N. 2006b. The Logic of Pre-Electoral Coalition Formation. Columbus: The Ohio State University Press.

Huskey, E \& G Iskakova. 2010. ‘The Barriers to Intra-Opposition Cooperation in the

Post-Communist World: Evidence from Kyrgyzstan'. Post-Soviet Affairs 26(3).

Ishiyama, J. 2009. 'Explaining "Minor" Party Nominations in Sub-Saharan Africa: The Cases of Ethiopia, Zambia, and Malawi' Journal of Asian and African Studies 44(3).

Jua, N. 2007. 'Deepening Democracy in Africa'. African Affairs 106(424).

Kadima, D (ed). 2006a. The Politics of Party Coalitions in Africa. Johannesburg: Konrad Adenauer Stiftung and EISA.

Kadima, D. 2006b. 'The Study of Party Coalitions in Africa: Importance, Scope, Theory and Research Methodology'. In D Kadima (ed). The Politics of Party 
Coalitions in Africa. Johannesburg: Konrad-Adenauer Stiftung and EISA. Kadima, D. 2006c. 'African Party Alliances: Comparisons, Conclusions and Lessons'. In The Politics of Party Coalitions in Africa. Johannesburg: KonradAdenauer Stiftung and EISA.

Kadima, D \& Z Matsimbe. 2006. 'RENAMO União Eleitoral: Understanding the Longevity and Challenges of an Opposition Party Coalition in Mozambique'. In The Politics of Party Coalitions in Africa. Johannesburg: Konrad-Adenauer Stiftung and EISA.

Kapa, M A. 2008. 'The Politics of Coalition Formation and Democracy in Lesotho'. Politikon 35(3).

Kraetzschmar, H. 2011. 'Mapping Opposition Cooperation in the Arab World: From Single-Issue Coalitions to Transnational Networks'. British Journal of Middle Eastern Studies 38(3).

LeVan, C. 2011. 'Power Sharing and Inclusive Politics in Africa's Uncertain Democracies'. Governance 24(1).

Lijphart, A. 1994. Electoral Systems and Party Systems: A Study of Twenty-Seven Democracies, 1945-1990. Oxford: Oxford University Press.

Lindberg, S. 2006. Democracy and Elections in Africa. Baltimore, MD: Johns Hopkins University Press.

Lindberg, S. 2007. 'Institutionalisation of Party Systems? Stability and Fluidity among Legislative Parties in Africa's Democracies'. Government and Opposition 42(2).

Lindberg, S (ed). 2009. Democratization by Elections: A New Mode of Transition. Baltimore, MD: Johns Hopkins University Press.

Oyugi, W O. 2006. 'Coalition Politics and Coalition Governments in Africa'. Journal of Contemporary African Studies 24(1).

Rakner, L \& L Svåsand. 2010. 'In Search of the Impact of International Support for Political Parties in New Democracies: Malawi and Zambia Compared'. Democratization 17(6).

Resnick, D. 2013. 'Do Electoral Coalitions Facilitate Democratic Consolidation in Africa?' Party Politics 19(5).

Sartori, G. 1976. Parties and Party Systems: A Framework for Analysis. Cambridge: Cambridge University Press.

Sartori, G. 1994. Comparative Constitutional Engineering: An Inquiry into Structures, Incentives and Outcomes. New York, NY: New York University Press.

Sriram, C Lekha \& M-J Zahar. 2009. 'The Perils of Power-Sharing: Africa and Beyond'. Africa Spectrum 44(3).

Stroh, A. 2010. 'The Power of Proximity: A Concept of Political Party Strategies Applied to Burkina Faso'. Journal of Contemporary African Studies 28(1).

Van de Walle, N. 2006 ‘Tipping Games: When Do Opposition Parties Coalesce?’ In 
ASchedler (ed). Electoral Authoritarianism: The Dynamics of Unfree Competition. Boulder, CO: Lynne Rienner.

Wahman, M. 2011. 'Offices and Policies: Why Do Oppositional Parties Form Pre-Electoral Coalitions in Competitive Authoritarian Regimes?' Electoral Studies 30(4).

Wahman, M. 2013. 'Opposition Coalitions and Democratization by Election'. Government and Opposition 48(1). 